\title{
Meningkatkan Kemampuan Pemecahan Masalah Matematis dan Self-Efficacy Siswa MTs Melalui Pendekatan Pendidikan Matematika Realistik
}

\author{
Susanti ${ }^{1}$ \\ ${ }^{1}$ Mathematics Education Departement, Universitas Islam Ar-raniry Banda Aceb \\ e-mail: susanti@ar-raniry.ac.id
}

\begin{abstract}
ABSTRAK. The purposes of this research is to the differences in mathematical problem-solving skills enhancement and self-efficacy among students who had learned Realistic Mathematics Education (RME) approach and students who received conventional instructions. Reseach use quasi-experimental was used pre-test research design posttest control group design. The experimental group was treated using RME approach while the control group gain use conventional approach. To gather the instrument is the form of mathematical problem solving ability test, and a questionnaire to determine students' self-efficacy toward mathematics. This research was conducted at Secondary Islamic School. The population is grade VIII students MTsN Model Banda Aceh inl year 2012/2013. The samples were two classes, VIII-7, class as the experimental class and the control class VIII-6, by purposive sampling technique. The researc found that studens mathematical problem-solving ability which were taken by with RME approach better than conventional approaches. Based on the analysis of self-efficacy RME class increases more than the self-efficacy of students who received conventional learning. Furthermore there a relationship between the ability of solving mathematical problems with self-efficacy of students in the experimental class and control with very low qualifications.
\end{abstract}

Keywords: Problem Solving Ability, Realistic Mathematics Education Approach (RME), Self-efficacy.

\section{INTRODUCTION}

Salah satu indikator keberhasilan siswa menguasai matematika dilihat pada hasil belajar matematika yang diperoleh siswa. Hasil yang diharapkan adalah hasil belajar matematika yang mencapai ketuntasan belajar matematika siswa. Rendahnya hasil belajar siswa dalam pelajaran matematika dibuktikan oleh survey yang dilakukan oleh Trends in International Mathematics and Science Study (TIMSS, 2011), menyatakan bahwa Indonesia berada pada urutan ke-38 dengan skor 386 dari 42 negara yang siswanya dites. Skor Indonesia ini turun 11 poin dari penilaian TIMSS pada tahun 2007. Hal ini disebabkan karena pembelajaran matematika di Indonesia masih menekankan pada menghafal rumus-rumus dan menghitung tanpa menekankan pada pemahaman konsep sehingga siswa kurang menyukai matematika.

Salah satu kompetensi matematika yang penting untuk dikembangkan oleh seorang guru adalah kompetensi kemampuan pemecahan masalah. Hal ini sesuai dengan yang dikemukakan oleh Barca (Syaiful, 2012) yaitu (1) kemampuan pemecahan masalah merupakan tujuan umum dalam pengajaran matematika, bahkan sebagai jantungnya matematika; (2) pemecahan masalah meliputi metode, prosedur, dan strategi merupakan proses inti dan utama dalam kurikulum matematika; dan (3) pemecahan masalah merupakan kemampuan dasar dalam belajar matematika. Dari pendapat Barca tersebut dapat disimpulkan bahwa kemampuan pemecahan masalah matematis haruslah dimiliki oleh setiap siswa sejak Sekolah Dasar (SD) sampai Perguruan Tinggi 
(PT). Melihat begitu pentingnya kemampuan pemecahan masalah matematis pada siswa maka peneliti tertarik untuk melakukan perbaikan terhadap kemampuan pemecahan matematis. Adapun indikator kemampuan pemecahan masalah yang dikembangkan pada penelitian ini adalah a) Mengidentifikasi kecukupan unsur dari suatu masalah geometri; b) Menyelesaikan masalah matematika; c) Menyelesaikan model matematika yang berhubungan dengan masalah nyata; d) Menggunakan matematika secara bermakna (Sumarmo, 2010).

Di lain pihak, memecahkan suatu masalah merupakan suatu aktivitas dasar bagi manusia, karena tujuan pendidikan pada hakekatnya adalah suatu proses terus menerus yang akan dilalui oleh manusia untuk menanggulangi masalah-masalah yang dihadapinya. Berdasarkan hal tersebut maka para siswa harus dilatih dan dibiasakan memecahkan masalah secara mandiri.

Berdasarkan hasil wawancara dengan guru bidang studi matematika di MTsN Model Banda Aceh, selama ini siswa merasa kesulitan dalam menyelesaikan masalah dalam bentuk soal-soal yang non rutin, siswa akan lebih mudah menyelesaikan soal geometri khususnya bangun ruang sisi datar dihadapkan pada soal yang yang dapat langsung diselesaikan tanpa butuh pemahaman secara mendalam, misalnya soal yang diketahui sisi-sisinya kemudian ditanya luas permukaan dan volume suatu bangun, namun ketika diberikan soal-soal dalam bentuk cerita atau soal pemecahan masalah siswa akan merasa kesulitan. Oleh sebab itu, maka perlu adanya suatu pendekatan matematika yang dapat meningkatkan kemampuan pemecahan masalah matematis siswa.

Salah satu pendekatan yang dipandang sebagai pendekatan pembelajaran matematika yang berpeluang besar bagi peningkatan hasil belajar matematika dan diharapkan dapat meningkatkan kemampuan siswa dalam pemecahan masalah matematis adalah pendekatan Pendidikan Matematika Realistik (Syaiful, 2012). Hal ini dikarenakan dalam pendekatan Pendidikan Matematika Realistik (PMR) pembelajaran dimulai dari sesuatu yang kongkrit sehingga siswa dapat terlibat dalam proses pembelajaran secara bermakna. Peran guru hanya sebagai pembimbing dan fasilitator bagi siswa. Siswa tidak dapat dipandang sebagai botol kosong yang harus diisi dengan air. Siswa adalah individu yang punya potensi untuk mengembangkan pengetahuan dalam dirinya. Siswa diharapkan aktif mengkonstruksi pengetahuannya. Bahkan di dalam pendekatan PMR diharapkan siswa tidak sekedar aktif sendiri, tetapi ada aktivitas bersama diantara mereka (interaktivitas). Proses pembelajaran seperti ini, diharapkan dapat meningkatkan kemampuan berpikir siswa secara optimal, terutama kemampuan pemecahan masalah matematis.

Pendekatan PMR merupakan salah satu pendekatan yang dapat membantu siswa dalam memecahkan masalah matematika. Dalam PMR, siswa diberi kesempatan untuk menemukan kembali dan merekonstruksi konsep-konsep matematika, sehingga siswa mempunyai pemahaman yang baik tentang konsep-konsep matematika. Dengan demikian, PMR akan mempunyai kontribusi yang sangat tinggi bagi siswa pada kehidupannya.

Selain kemampuan pemecahan masalah matematis, terdapat aspek lain yang juga memberikan pengaruh yang signifikan yaitu aspek psikologis. Aspek psikologis ini turut memberikan kontribusi terhadap keberhasilan seseorang dalam menyelesaikan tugas/soal dengan baik, aspek psikologis tersebut adalah self-efficacy. Self-efficacy merupakan salah satu faktor penting dalam menentukan prestasi matematika seseorang. Self-efficacy berkaitan dengan penilaian seseorang terhadap kemampuan dirinya sendiri dalam menyelesaikan suatu tugas tertentu. Penilaian kemampuan diri yang akurat merupakan hal yang sangat penting, karena perasaan positif yang tepat tentang self-efficacy dapat mempertinggi prestasi, meyakini kemampuan, mengembangkan motivasi internal, dan memungkinkan siswa untuk meraih tujuan yang menantang (Bandura, 2006: 308).

Self-efficacy memiliki pengaruh dalam pemilihan perilaku dan ketekunan, serta pola berpikir dan reaksi emosional. Penilaian self-efficacy mendorong individu menghindari situasi yang diyakini melampaui kemampuannya atau melakukan kegiatan yang diperkirakan dapat diatasinya. Dalam memecahkan masalah yang sulit, individu yang mempunyai keraguan tentang kemampuannya akan mengurangi usahanya bahkan cenderung akan menyerah. Individu yang mempunyai efficacy tinggi menganggap kegagalan sebagai kurangnya usaha, sedangkan individu yang memiliki efficacy rendah 
menganggap kegagalan berasal dari kurangnya kemampuan. Perlu diperhatikan bahwa keyakinan diri yang dipersepsikan seseorang memainkan peranan kunci dalam kehidupan manusia, karena hal tersebut memberi pengaruh pada perilaku manusia secara keseluruhan seperti kepercayaan, emosi, pemikiran dan dua tindakan (Bandura, 2006). Siswa yang memiliki self-efficacy rendah akan cenderung ragu-ragu dalam penyelesaian masalah matematika. Sebaliknya siswa yang memiliki self-efficacy tinggi akan sangat yakin dengan yang akan dikerjakannya. Dalam mengatasi permasalahan inilah, para guru dapat menggunakan suatu pendekatan yang inovatif. Pendekatan PMR merupakan salah satu solusi yang dapat meningkatkan self-efficacy siswa. Karena dalam pendekatan PMR siswa lebih diberi kebebasan dalam mengeluarkan ide tanpa harus terikat dengan suatu algoritma tertentu.

Berdasarkan uraian di atas, maka peneliti tertarik untuk melakukan suatu penelitian yang berjudul "Meningkatkan Kemampuan Pemecahan Masalah Matematis dan Self-Efficacy Siswa MTs Melalui Pendekatan Pendidikan Matematika Realistik”.

\section{METODE PENELITIAN}

Penelitian ini merupakan penelitian eksperimen dengan pendekatan kuantitatif. Fraenkel et. al (1993) menyatakan bahwa penelitian eksperimen adalah penelitian yang melihat pengaruhpengaruh dari variabel bebas terhadap satu atau lebih variabel lain dalam kondisi yang terkontrol. Desain penelitian pada penelitian ini berbentuk "pretest-postest control group", dalam penelitian ini melibatkan dua kelas, yakni kelas yang diajarkan dengan pendekatan PMR sebagai kelas kontrol dan kelas yang diajarkan tanpa PMR(konvensional) sebagai kelas kontrol. Gambaran tentang desain dapat digambarkan seperti berikut:

\section{Keterangan :}

\begin{tabular}{lcc}
$\mathrm{O}$ & $\mathrm{X}$ & $\mathrm{O}$ \\
$\mathrm{O}$ & - & $\mathrm{O}$ \\
\hline
\end{tabular}

$\mathrm{X} \quad$ : Pembelajaran dengan pendekatan PMR

$\mathrm{O} \quad$ : Tes yang diberikan untuk mengetahui kemampuan siswa (pretes $=$ postes)

Dalam penelitian ini menggunakan dua variable yaitu variabel bebas dan variabel terikat. Variabel bebas adalah variabel yang mempengaruhi atau yang menjadi sebab perubahan atau timbulnya variabel terikat (Sugiyono, 2013:61). Dalam penelitian ini yang menjadi variabel bebas adalah pembelajaran matematika dengan menggunakan pendekatan PMR. Variabel terikat adalah variabel yang dipengaruhi atau yang menjadi akibat karena adanya variabel bebas (Sugiyono, 2013:61). Dalam penelitian ini yang menjadi variabel terikat adalah kemampuan pemecahan masalah matematis dan self-efficacy.

Populasi dalam penelitian ini adalah seluruh siswa kelas VIII MTsN Model Banda Aceh. Sampel dalam penelitian ini adalah siswa kelas $\mathrm{VIII}_{7}$ sebagai kelas eksperimen dan kelas $\mathrm{VIII}_{6}$ sebagai kelas kontrol yang dipilih secara purposive sampling yaitu pemilihan sampel dengan pertimbangan dimana kedua kelas tersebut memiliki kemampuan awal yang sama hal ini diuktikan dari nilai matematika semester ganjil tahun pelajaran 2012-2013. Data dalam dalam penelitian ini didapat dari dua macam instrumen, yaitu instrumen kemampuan pemecahan masalah matematis yang berupa lembar tes uraian dan intrumen self-efficacy matematika siswa yang berbentuk angket.

Metode pengumpulan data dalam penelitian ini yaitu menggunakan metode tes dan angket self-efficacy. Metode tes ini digunakan untuk mengetahui kemampuan pemecahan masalah matematis siswa setelah diajarkan dengan pendekatan realistik dibandingkan dengan kemampuan pemecahan masalah matematis siswa yang diajarkan tanpa menggunakan pendekatan matematika realistik. Angket self-efficacy diberikan kepada kepada siswa sebelum dan sesudah diterapkan pendekatan matematika realistik untuk melihat bagaimana kepercayaan diri siswa terhadap pembelajaran matematika.

Data yang dianalisis pada penelitian ini, diperoleh dari tes kemampuan pemecahan masalah matematis dan angket self-efficcay siswa, dihitung N-Gain (gain ternormalisasi). Perhitungan NGain dilakukan dengan tujuan untuk menghilangkan faktor tebakan dan efek nilai tertinggi 
sehingga terhindar dari kesimpulan yang bias (Hake, 1999; Heckler, 2004). Rentang nilai N-gain adalah 0 sampai dengan 1. Selanjutnya, nilai N-Gain inilah yang diolah, dan pengolahannnya disesuaikan dengan permasalahan dan hipotesis yang diajukan. Pengolahan data dalam penelitian ini dilakukan sebagai berikut: (1) menguji persyartan statistik yang diperlukan sebagai dasar dalam pengujian hipotesis yaitu menguji normalitas dan homogenitas data baik terghadap bagianbagiannya maupun secara keseluruhan. Uji normalitas dan homogenitas ini menggunakan Shapiro-Wilk dan uji Levene. (2) Uji-t untuk mengetahui adanya perbedaan peningkatan yang signifikan antara kedua kelas. Seluruh perhitungan menggunakan bantuan komputer program SPSS 19.

\section{HASIL PENELITIAN DAN PEMBAHASAN}

\section{Hasil Penelitian Kemampuan Pemecahan Masalah Matematis}

Analisis Awal Kemampuan Pemecahan Masalah Matematis

Skor hasil pretes kemampuan pemecahan masalah matematis siswa diperoleh sebelum pembelajaran baik kelas eksperimen maupun kelas kontrol dapat disajikan pada diagram batang pada Gambar 1 berikut ini:

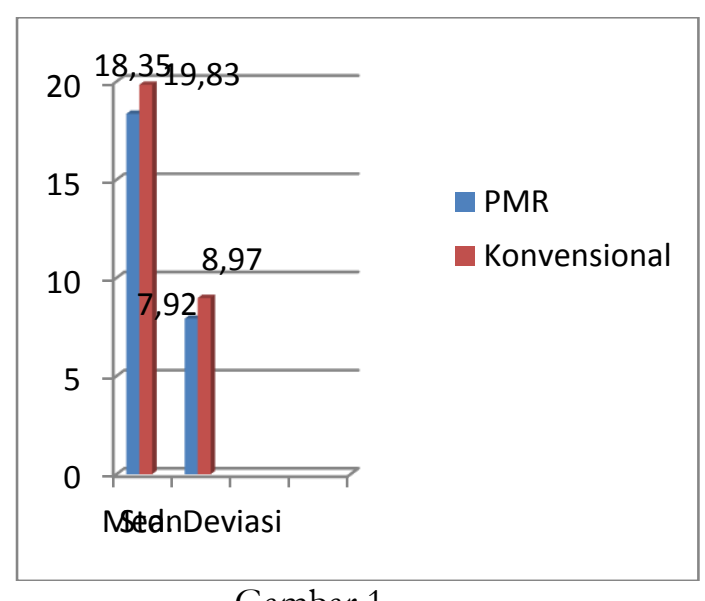

Gambar 1

Diagram Mean dan Standar Deviasi pretes Kemampuan Pemecahan Masalah Matematis Kelas Ekperimen dan Kelas Kontrol

Dari Gambar 1 menunjukkan bahwa, rata-rata hasil pretes kelas eksperimen dan kelas kontrol memiliki perbedaan. Rata-rata pretes kelas eksperimen (warna biru) lebih rendah dari pada rata-rata pada kelas kontrol (warna merah). Namun standar deviasi kelas eksperimen lebih kecil daripada kelas kontrol, ini menunjukkan bahwa sebaran data kelas eksperimen lebih baik daripada kelas kontrol. Namun demikian rata-rata kedua kelas tersebut relatif sama.

\section{Analisis Peningkatan Kemampuan Pemecahan Masalah Matematis}

Perbandingan rata-rata N-Gain dan standar deviasi kemampuan pemecahan masalah matematis antara kelompok eksperimen dan kelompok kontrol disajikan dalam diagram batang pada Gambar 2 berikut ini: 


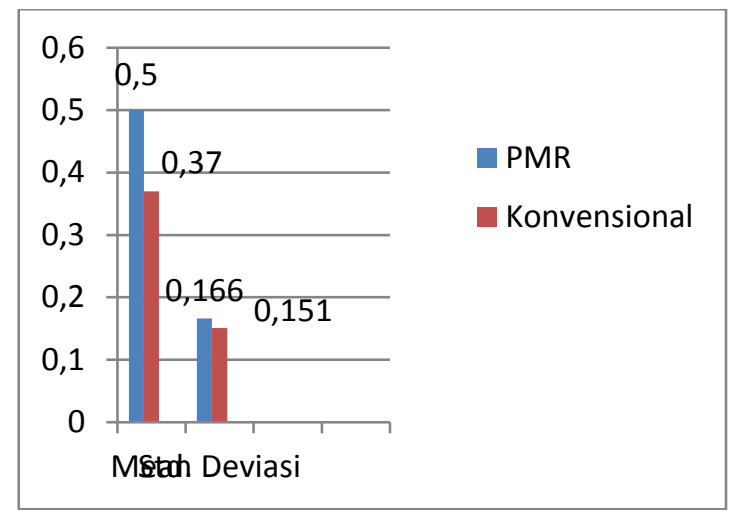

Gambar 2

Diagram Mean dan Standar Deviasi N-Gain Kemampuan Pemecahan Masalah Matematis Berdasarkan Pendekatan Pembelajaran.

Dari Gambar 2 terlihat bahwa rata-rata peningkatan kemampuan pemecahan masalah matematis siswa yang mendapatkan pembelajaran dengan pendekatan PMR (warna biru) lebih meningkat dari siswa yang mendapatkan pembelajaran dengan pendektan konvensional (warna merah) untuk keseluruhan siswa. Untuk mengetahui signifikansi kebenaran data perlu dilakukan perhitungan statistik dengan menggunkan uji perbedaan rata-rata terhadap populasi. Sebelum melakukan uji perbedaan rata-rata diperlakukan uji normalitas dan homogenitas terhadap skor gain kemampuan pemecahan masalah matematis untuk kelas eksperimen dan kelas kontrol. Hasil uji normalitas dan homogenitas dapat dilihat pada Tabel 1 berikut ini:

Tabel 1. Uji Normalitas dan Homogenitas Tes Kemampuan Pemecahan Masalah Matematis

\begin{tabular}{ccccccc}
\hline \multicolumn{1}{c}{ Tes } & \multirow{2}{*}{ Kelas } & \multicolumn{2}{c}{ Normalitas } & \multicolumn{2}{c}{ Homogenitas } \\
\cline { 3 - 5 } \cline { 3 - 5 } N-Gain & & Sig. & Ket & Sig. & Ket. \\
\cline { 2 - 5 } & Eksperimen & 0,711 & Normal & 0,85 & Homogen \\
\cline { 2 - 4 } & Kontrol & 0,999 & Normal & 0 & \\
\hline
\end{tabular}

Berdasarkan Tabel 1 diperoleh normalitas skor gain kemampuan pemecahan masalah matematis kelas ekperimen dan kelas kontrol adalah sig. 0,711 dan 0,999 > 0,05 dengan mengambil taraf signifikan $\alpha=0,05$. Maka dapat disimpulkan bahwa sebaran data untuk kelas eksperimen dan kelas kontrol berdistribusi normal. Selanjutnya homogenitas skor gain kemampuan pemecahan masalah matematis siswa didapat sig. 0,850 dengan taraf signifikan $\alpha=$ 0,05 makan 0,850 > 0,05 artinya varian siswa kelas eksperimen dan kelas kontrol homogen. Selanjutnya, akan dilakukan uji perbedaan rata-rata dengan menggunkan uji-t, menggunakan Compare Mean Independen Sampel Test dengan taraf signifikan $\alpha=0,05$. Hasil uji perbedaan rata-rata dapat dilihat pada rangkuman hasil perhitungan yang ditunjukkan pada Tabel 2 berikut ini:

Tabel 2. Uji Perbedaan Rata-rata Skor Gain Kemampuan Pemecahan Masalah Matematis

\begin{tabular}{clccc}
\hline Aspek & \multicolumn{1}{c}{ Kelas } & T & Df & Sig. \\
\hline \multirow{2}{*}{ N-Gain } & Eksperimen & 3,17 & \multirow{2}{*}{60} & 0,00 \\
& Kontrol & 7 & & 1 \\
\hline
\end{tabular}

Dari Tabel 2 untuk $\alpha=0,05, \mathrm{t}_{(1-\alpha)} \mathrm{dk}=60$ dan uji-t satu sampel independent untuk pembelajaran dengan PMR (eksperimen) dan konvensional (kelas kontrol) maka signifikansi adalah 0,001. Karena Asymp.sig $=0,001<0,05=\alpha$, maka $H_{o}$ ditolak, sehingga $H_{a}$ diterima. Ini memberi kesimpulan bahwa Peningkatan kemampuan pemecahan masalah matematis siswa kelas 
eksperimen lebih baik daripada peningkatan kemampuan pemecahan masalah matematis siswa kelas kontrol.

\section{Hasil Penelitian tentang Self-Efficacy}

Data selfefficacy siswa diperoleh dari pemberian angket skala yang tersusun dari 29 pernyataan yang terdiri dari 16 pernyaataan positif dan 13 pernyataan negatif. Angket skala selfefficacy diberikan pada kelas eksperimen dan kelas kontrol pada awal dan akhir pembelajaran. Data skor angket self-efficacy yang diperoleh berupa data ordinal yang selanjutnya dikonversi menjadi data interval dengan menggunakan Methode of Successive Interval.

\section{Analisis Self-Efficacy Awal Siswa terhadap Matematika}

Hasil dari angket skala yang diberikan sebelum pembelajaran pada kedua kelas setelah dilakukan pengolhan data hasil angket skala self-efficacy siswa diperoleh rata-rata dan standar deviasi dapat dilihat pada diagram Gambar 3 berikut ini:

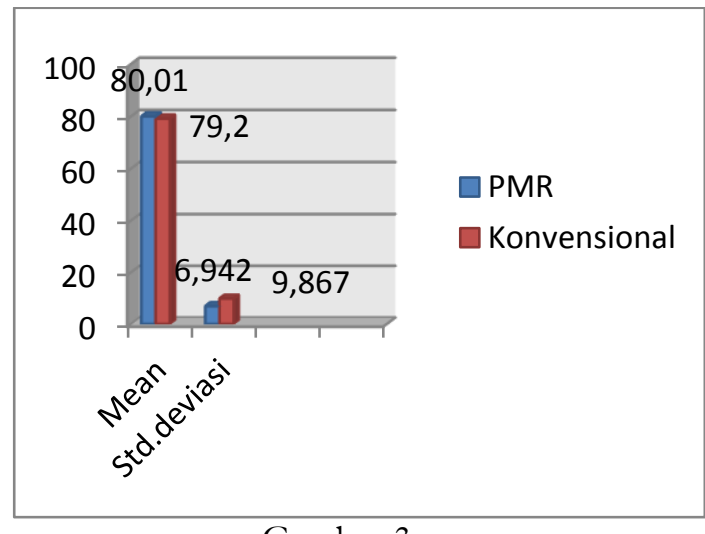

Gambar 3

Diagram Mean dan Standar Deviasi pretes Self-Efficacy Kelas Ekperimen dan Kelas Kontrol

Dari Gambar 3 menujukkan rata-rata kelas eksperimen lebih baik 0,81\% dari rata-rata kelas kontrol, sedangkan untuk standar deviasi didapat 6,942 untuk kelas eksperimen dan 9,867 untuk kelas kontrol. hasil angket skala didapat pada kelas ekperimen dan kelas kontrol tidak jauh berbeda. Kelas eksperimen memperoleh rata-rata 80,1 dan kelas kontol memperoleh 79,20. Hal ini menunjukkan bahwa kedua kelas memiliki pandangan yang hampir sama terhadap matematika.

\section{Analisis Peningkatan Self-Efficcay Siswa terhadap Matemtika}

Untuk melihat peningkatan self-efficacy siswa terhadap matematika siswa digunakan data gain ternormalisasi. Sehingga data yang dianalisis dalam penelitian ini adalah skor gain yang telah ternormalkan. Rata-rata skor gain ternormalkan merupakan gambaran peningkatan self-efficacy lebih baik dengan pendekatan PMR maupun dengan pembelajaran konvensional. Perbandingan ratarata N-Gain dan standar deviasi self-efficacy siswa terhadap matematika antara kelompok eksperimen dan kelompok kontrol disajikan dalam diagram batang pada Gambar 4 berikut ini:

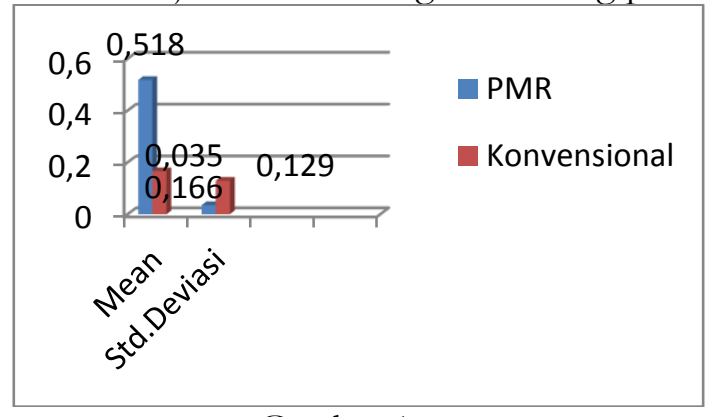

Gambar 4

Diagram Mean dan Standar Deviasi N-Gain Self-Efficacy Kelas Ekperimen dan Kelas Kontrol

Berdasarkan Gambar 4 di atas terdapat beberapa kesimpulan yang berkaitan self-efficacy siswa terhadap matematika yaitu rata-rata skor gain self-efficacy siswa terhadap matematika kelas eksperimen tergolong ke dalam kategori sedang, sedangkan rata-rata skor gain self-efficacy siswa 
terhadap matematika kelas kontrol tergolong ke dalam kategori rendah. Rata-rata skor gain selfefficacy siswa terhadap matematika kelas eksperimen $(0,518)$ lebih tinggi dibandingkan dengan rata-rata skor gain self-efficacy siswa terhadap matematika kelas kontrol $(0,166)$. Untuk mengetahui signifikansi kebenaran kesimpulan di atas perlu dilakukan perhitungan pengujian statistik dengan menggunakan uji perbedaan rata-rata dua populasi terhadap hipotesis berikut. Hasil uji normalitas dan homogenitas dapat dilihat pada Tabel 2 berikut ini:

Tabel 3. Uji Normalitas dan Homogenitas Self-Efficacay Siswa

\begin{tabular}{clrl}
\hline \multicolumn{1}{c}{ Tes } & \multirow{2}{*}{ Kelas } & \multicolumn{2}{c}{ Normalitas } \\
\cline { 3 - 4 } \cline { 3 - 4 } N-Gain & & Sig. & \multicolumn{1}{c}{ Ket. } \\
\cline { 3 - 4 } & Eksperimen & 0,200 & Normal \\
\cline { 3 - 4 } & Kontrol & & Tidak Normal \\
\hline
\end{tabular}

Dari Tabel.3 menujukkan bahwa signifikan pada kelas kontrol kurang dari $\alpha=0,05$ yaitu 0,00 sehingga data gain pada kelas kontrol tidak berdistribusi normal. Karena salah sutu data tidak berdistribusi normal maka untuk menguji perbedaan dua rata-rata menggunakan uji non parametrik dalam hai ini uji nonparametrik yang dipilih adalah uji Mann-Whitney. Karena data tidak berdistribusi normal, maka analisi statistik pengujian perbedaan rata-rata dua sampel dilakukan uji statistik non-parametrik yaitu uji Mann-Whitney. Analisis ini dilakukan untuk melihat pengaruh langsung dari perlakuan yang berbeda pada kelas eksperimen dan kelas kontrol terhadap self-efficacy siswa terhadap matematika.

Tabel 4. Hasil Uji Perbedaan Dua Rata-rata Skor Skala Self-Efficacy Siswa Kelas Eksperimen dan Kelas Kontrol

\begin{tabular}{|l|c|}
\hline & Postes kelas eksperimen dan control \\
\hline Mann-Whitney U & 252,000 \\
Wilcoxon W & 687,000 \\
Z & $-3,202$ \\
Asymp. Sig. (2-tailed) &, 001 \\
\hline
\end{tabular}

Dari Tabel 4 di atas terlihat bahwa nilai signifikansi (sig.) sebesar 0,001 lebih kecil dari $\alpha=$ 0,05. Karena uji yang digunakan adalah uji satu pihak maka besarnya probabilitas penolakan $\mathrm{H}_{\mathrm{o}}$ adalah $\frac{1}{2} \times \operatorname{sig}=\frac{1}{2} \times 0,001=0,0005<\alpha$ sehingga dapat disimpulkan bahwa hipotesis nol yang menyatakan tidak terdapat perbedaan rata-rata kedua kelas, ditolak. Berarti, peningkatan Peningkatan self-efficacy siswa terhadap matematika kelas eksperimen lebih baik daripada peningkatan self-efficacy siswa terhadap matematika kelas kontrol.

Koefisien Korelasi antara Self-Efficacy dengan Kemampuan Pemecahan Masalah Matematis

Kelas Eksperimen

Tabel 5. Hasil Uji Korelasi Self-Efficacy dan Kemampuan Pemecahan Masalah Matematis Kelas Eksperimen

\begin{tabular}{llrr}
\hline & & \multicolumn{3}{c}{ self-efficacy } & pemecahan masalah \\
\hline \multirow{2}{*}{ Self-Efficacay } & \multicolumn{1}{l}{ Pearson Correlation } & 1 &, 019 \\
\cline { 2 - 4 } & Sig. (2-tailed) & 33 &, 917 \\
\cline { 2 - 4 } & $\mathrm{N}$ &, 019 & 33 \\
\hline \multirow{2}{*}{ Pemecahan Masalah } & Pearson Correlation &, 917 & 1 \\
\cline { 2 - 4 } & Sig. (2-tailed) & 33 & 33 \\
\cline { 2 - 4 } & $\mathrm{N}$ & & \\
\hline
\end{tabular}


Dari Tabel. 5 diperoleh hasil korelasi antara self-efficacy dan kemampuan pemecahan masalah matematis siswa kelas eksperimen adalah 0,019 dan nilai signifikansi (sig) sebesar 0,917. Harga korelasi $(r)$ yang diperoleh adalah 0,019 yang artinya tingkat hubungannya tergolong sangat rendah. Karena nilai signifikansi 0,917 lebih besar dari $\alpha=0,05$ maka tidak terdapat hubungan yang signifikan antara self-efficacy dan kemampuan pemecahan masalah matematis siswa. Harga koefisien determinannya dihitung dengan rumus $\mathrm{KD}=r^{2} \times 100 \%$ (Ridwan, 2004), dan diperoleh harganya sebesar $0,03 \%$ yang artinya bahwa $0.03 \%$ variasi di dalam pemecahan masalah matematis dapat dijelaskan oleh variasi dalam self-efficacy.

\section{Kelas Kontrol}

Tabel 6. Hasil Uji Korelasi Self-Efficacy dan Kemampuan Pemecahan Masalah Matematis Kelas Kontrol

\begin{tabular}{llrr}
\hline & & self-efficacy & pemecahan masalah \\
\hline \multirow{2}{*}{ Self-Efficacay } & Correlasi coefisien & 1 &, 037 \\
\cline { 2 - 4 } & Sig. (2-tailed) & &, 849 \\
\cline { 2 - 4 } Pemecahan Masalah & $\mathrm{N}$ & 29 & 29 \\
\cline { 2 - 4 } & Correlasi coefisien &, 037 & 1 \\
\cline { 2 - 4 } & Sig. (2-tailed) & 849 & 33 \\
\cline { 2 - 4 } & $\mathrm{N}$ & 33 & \\
\hline
\end{tabular}

Dari Tabel 6 diperoleh hasil korelasi antara selfefficacy dan kemampuan pemecahan masalah matematis siswa kelas kontrol adalah 0,037 dan nilai signifikansi (sig) sebesar 0,849. Harga korelasi $(r)$ yang diperoleh adalah 0,037 yang artinya tingkat hubungannya korelasinya sangat rendah. Karena nilai signifikansi 0,849 lebih besar dari $\alpha=0,05$ maka tidak terdapat hubungan yang signifikan antara self-efficacy dan kemampuan pemecahan masalah matematik siswa. Harga koefisien determinannya dihitung dengan rumus $\mathrm{KD}=r^{2} \times 100 \%$ (Ridwan, 2004), dan diperoleh harganya sebesar $0,13 \%$ yang artinya bahwa $0,13 \%$ variasi di dalam pemecahan masalah matematis dapat dijelaskan oleh variasi dalam self-efficacy.

\section{Pembahasan}

Berdasarkan analisis data hasil penelitian, diketahui bahwa pembelajaran dengan menggunakan pendekatan PMR memiliki pengaruh terhadap kemampuan pemecahan masalah matematis siswa. Hal ini diketahui dan diperoleh dengan adanya perbedaan rata-rata skor gain kemampuan pemecahan masalah matematis yang diperoleh siswa pada kelas eksperimen dan kelas kontrol setelah proses pembelajaran. Setelah peneliti melakukan pembelajaran dengan menggunakan pendekatan PMR pada siswa kelas eksperimen dan pembelajaran konvensional pada siswa kelas kontrol, hasil analisis yang diperoleh ternyata mendukung hipotesis yang menyatakan bahwa kemampuan pemecahan masalah matematis siswa yang memperoleh pembelajaran dengan menggunakan pendekatan PMR lebih baik dari siswa yang memperoleh pembelajaran konvensional.

Penelitian ini relevan dengan penelitian Syaiful (2012) yang mengemukakan bahwa peningkatan kemampuan pemecahan masalah matematis pada kelas yang diberi pembelajaran dengan pendekatan PMR lebih baik dibandingkan dengan kelas yang diberi pembelajaran konvensional. Hal ini dikarenakan siswa yang memperoleh pembelajaran dengan pendekatan PMR dibiasakan menyelesaikan soal yang berbentuk kontektual atau soal yana dibuat lebih berhubungan dengan kehidupan sehari-hari siswa, sehingga siswa dapat dengan mudah menyelesaikan soal tersebut. Serta lebih memberi kebebasan kepada siswa dalam berpendapat dan mengembangkan suasana diskusi dan tanya jawab sehingga terjadi interaksi antara siswa dengan guru maupun siswa dengan siswa.

Interaksi tersebut dapat memberdayakan kemampuan kognitif siswa secara optimal, menumbuhkan keberanian dan kepercayaan diri siswa. Kondisi pembelajaran seperti ini diyakini dapat mengembangkan kemampuan pemecahan masalah matematis. Hal inilah yang terdapat 
dalam pembelajaran dengan pendekatan PMR, siswa menjadi lebih aktif dan berani dalam mengungkapkan pendapat dan siswapun memiliki keyakinan dalam menjawab pertanyaan yang diberikan oleh guru.

Pengaruh pembelajaran dengan pendekatan PMR juga dilihat terhadap peningkatan kemampuan pemecahan masalah matematis pada siswa kelas eksperimen dan siswa kelas kontrol. Peningkatan yang terjadi diukur dengan menggunakan skor gain siswa kedua kelas. Berdasarkan hasil analisis skor gain, diketahui bahwa rata-rata gain siswa kelas eksperimen tergolong ke dalam kategori sedang $(0,5)$ dan rata-rata gain siswa kelas kontrol tergolong ke dalam kategori rendah $(0,38)$. Hasil di atas menandakan bahwa peningkatan kemampuan pemecahan masalah matematis terjadi pada semua kelas, baik eksperimen maupun kontrol.

Peningkatan kemampuan pemecahan masalah matematis siswa yang memperoleh pembelajaran dengan pendekatan PMR masih termasuk kategori sedang dikarenakan siswa belum terbiasa dengan soal-soal pemecahan masalah.

Hasil analisis secara statistik juga menunjukkan bahwa peningkatan kemampuan pemecahan masalah matematis siswa kelas eksperimen lebih baik daripada peningkatan kemampuan pemecahan masalah matematis siswa kelas kontrol. Hal ini berarti, pembelajaran dengan pendekatan PMR mempunyai pengaruh terhadap peningkatan kemampuan pemecahan masalah matematis siswa.

Penelitian ini membuktikan hipotesis bahwa kemampuan pemecahan masalah matematis siswa yang memperoleh pembelajaran dengan pendekatan PMR lebih baik daripada siswa yang memperoleh pembelajaran konvensional.

Hasil di atas menunjukan bahwa pembelajaran dengan pendekatan PMR yang diterapkan pada kelas eksperimen secara bertahap telah membiasakan siswa menyelesaika permasalah matematis yang lebih kontektual, yang dapat membantu siswa lebih mudah memahami masalah yang merupakan salah satu tahapan dalam menyelesaian pemecahan masalah matematis. Selain itu siswa juga terbiasa mengaitkan pengalaman nyata dalam kehidupan sehari-hari dengan konsep matematika yang telah mereka miliki.

Penggunaan model dalam matematika yang terdapat dalam pembelajaran dengan pendekatan PMR telah memberikan kontribusi terhadap pemecahan masalah matematik seperti yang diungkapkan oleh Ang Keng Cheng (2009) dalam Handayani (2011) bahwa pemodelan matematikaa merupakan proses representasi masalah kontekstual ke dalam istilah/model matematika untuk menemukan solusi/penyelesaian masalah tersebut atau untuk meningkatkan pemahaman suatu masalah.

Hasil penelitian self-efficacy siswa pada kelas eksperimen menunjukkan bahwa sebelum dan sesudah perlakuaan terlihat adanya perkembangan. Sebelum diberikan perlakuan siswa kurang percaya diri hal ini terlihat ketika guru memberikan pretes siswa banyak yang menyontek dan kurang yakin dengan jawaban sendiri. Selain itu pada saat pertemuan pertama guru meminta siswa untuk memberikan pendapat tentang bagaimana perasaan mereka terhadap matematika, mereka mengatakan bahwa kurang menyukai matematika.

Dari hasil analisis terhadap nilai pretes self-efficacy siswa menunjukkan bahwa perasaan siswa terhadap matematika antara kelas eksperimen dan kelas kontrol tidak berbeda, hal ini diperoleh dari hasil angket self-efficcay siswa. Setelah diberikan perlakuan pada kelas eksperimen dan kontrol didapat hasil postes self-efficacy siswa menujukkan bahwa peningkatan self-efficacy siswa kelas eksperimen lebih baik daripada self-efficacy siswa kelas kontrol. Artinya bahwa siswa kelas eksperimen memiliki keyakinan bahwa kemampuannya untuk dapat menyelesaikan soal/tugas pemecahan masalah matematis dengan berhasil. Hasil ini sesuai dengan penelitian sebelumnya, Handayani (2011) yang mengemukakan bahwa self-efficacy kelas siswa yang memperoleh pembelajaran model method lebih baik daripada self-efficacy kelas siswa yang memperoleh pembelajaran konvensional.

Selain menggunakan angket, berdasarkan hasil observasi peneliti dapat disimpulkan bahwa siswa kelas eksperimen memiliki self-efficacy yang tinggi untuk bertanya kepada guru, maupun 
mengerjakan soal di papan tulis berdasarkan prosedur pemodelan yang diminta. Siswa telah merasa yakin dengan jawaban mereka dikarenakan representasi yang dibuat telah mengarahkan siswa untuk menyelesaikan soal dengan benar. Hasil ini sesuai dengan pendapat Verschaffel \& de Corte, Lesh \& Doerr dan Gravemeijer (dalam Handayani, 2011) yang menyatakan bahwa penyelesaian masalah matematis saat ini difokuskan terhadap sikap dan keyakinan siswa dan kapasitas mereka untuk mengaplikasikan pengetahuan matematika dalam masalah-masalah yang bersifat non-rutin. Mereka juga mendokumentasikan bahwa keyakinan yang kuat dari siswa dapat berfungsi sebagai alat untuk meramalkan (predictor) keberhasilan dan prestasi siswa dalam penyelesaian masalah yang autentik. Faktor keyakinan ini dimunculkan beberapa ahli sebagai faktor yang efektif dalam mengerjakan tugas-tugas pemecahan masalah.

\section{SIMPULAN}

Berdasarkan hasil penelitian, peneliti menemukan bahwa kemampuan pemecahan masalah matematika yang dipelajari dengan pendekatan RME lebih baik daripada pendekatan konvensional. Berdasarkan analisis self efficacy kelas RME meningkat lebih dari self-efficacy siswa yang mendapat pembelajaran konvensional. Selanjutnya, ada hubungan antara kemampuan memecahkan masalah matematika dengan self-efficacy siswa di kelas eksperimen dan kontrol dengan kualifikasi sangat rendah.

\section{REFERENSI}

Bandura. A. (1994). Self-efficacy. Dalam V. S. Ramachaudran (Ed.), Encyclopedia of Human Behavior, Vol. 4. New York: Academic Press. [online]. Tersedia: http://www.des.emory.edu/mfb/BanEncy.html . (2006). Guide for Constructing Self-Efficacy Scales Dalam Frank Pajares \& Tim Urdan

(Ed)., Self-Efficacy Beliefs of Adolecents. [Online]. Tersedia: http://www.des.emory.edu/mfp/self-efficacy.html\#books

Barry, J. Zimmerman. (2000). Self-Efficacy: An Essensial Motive to Learn. [Online]. Tersedia: http://www.idealibrary.com

Gravemeijer, K. (1994). Developing Realistic Mathematics Education. Utrecht: Freudenthal Institut. Netherland.

Handayani, Isnaini. (2009). Penggunaan Model Method dalam Pembelajaran Pecaban sebagai Upaya

Hake, R.R. (1999). Analyzing Change/Gain Scores. [Online]. Tersedia: http://www.physics.indiana.edu/ sdi/Analyzingchange-Gain.pdf

Saiful. (2012). Meningkatkan Kemampuan Pemecahan Masalab Matematik dan Self-Efficacy Siswa SD. Tesis. UPI: Tidak diterbitkan.

Syaiful. (2012). Peningkatan Kemampuan Pemecahan Masalah Matematis Melalui Pendekatan PendidikanMatematika Realistik. Jurnal Pendidikan Matematika dan Sains, Vol 02, No. 01, ISSN: 2088-2157

Sugiyono. (2013). Metode Penelitian Pendidikan. Bandung: Alfabeta.

TIMSS. (2011). International Association for the Evaluation of Educational Achievement. 